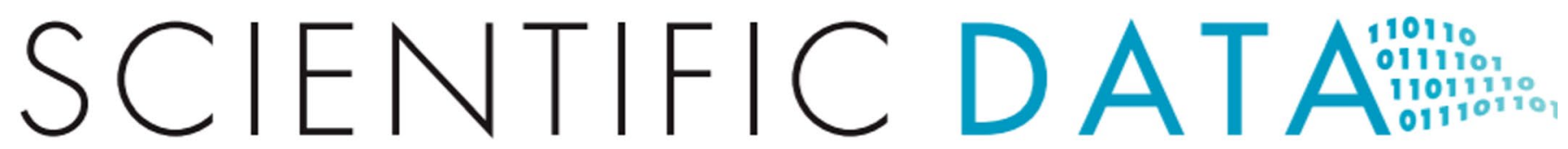

Check for updates

OPEN

DATA DESCRIPTOR

\title{
A salmon diet database for the North Pacific Ocean
}

\author{
Caroline Graham $\mathbb{1}^{1,2 \bowtie}$, Evgeny A. Pakhomov $\mathbb{1}^{1,2,3}$ \& Brian P. V. Hunt $\mathbb{1}^{1,2,3}$
}

The North Pacific Marine Salmon Diet Database is an open-access relational database built to centralize and make accessible salmon diet data through a standardized database structure. The initial data contribution contains 21,862 observations of salmon diet, and associated salmon biological parameters, prey biological parameters, and environmental data from the North Pacific Ocean. The data come from 907 unique spatial areas and mostly fall within two time periods, 1959-1969 and 19871997 , during which there are more data available compared to other time periods. Data were extracted from 62 sources identified through a systematic literature review, targeting peer-reviewed and gray literature. The purpose of this database is to consolidate data into a common format to address gaps in our ecological understanding of the North Pacific Ocean, particularly with respect to salmon. This database can be used to address a variety of questions regarding salmon foraging, productivity, and marine survival. The North Pacific Marine Salmon Diet Database will continue to grow in the future as more data are digitized and become available.

\section{Background \& Summary}

Even though salmon spend 1-6 years of their life in the marine environment, this phase of their life cycle is poorly understood compared to their freshwater phase ${ }^{1}$. There are limited data on how salmon are distributed, what they feed on, and what threats to survival they may face during this phase, which includes nearshore and offshore components. The marine phase is hypothesized to contain salmon population bottlenecks ${ }^{2}$, and research has shown that salmon smolt to adult survival rates can be less than $1 \%$ for some stocks in the North Pacific ${ }^{3}$. There is also evidence that Pacific salmon marine survival has been declining over the past several decades in certain areas, especially more southern stocks ${ }^{4,5}$. Therefore, it is becoming urgent that researchers understand what is happening to salmon during the marine phase of their life cycle, especially after they have moved offshore, because this phase tends to be data-poor compared to the early marine coastal phase.

One of the most important factors affecting salmon survival is the presence and abundance of suitable prey. Although it is difficult to assess prey distribution across ocean basins, information on prey presence and abundance can be derived from salmon diets. Marine diet data has the potential to give insight into food webs, niche overlap among species/stocks, competition, health, and changing ocean conditions ${ }^{6-8}$. Since the early 1900 s, researchers have been examining the diets of Pacific salmon to provide information on species biology and the conditions that salmon face in the ocean ${ }^{9,10}$. Although there have been some reviews of salmon diet data in the North Pacific, these have been limited in time and space and the data are not normally made publicly available $\mathrm{e}^{7,8,11-15}$.

Salmon diet data have been collected using a variety of methodologies employed by researchers from countries across the North Pacific. These data are scattered across the peer-reviewed and gray literature, making collation challenging. However, there is high value in collating these data, considering the costliness and difficulty of conducting fieldwork in the open ocean. Synthesizing these data can reveal important information about salmon open ocean life history experience and further understanding of the potential impacts of changing oceans on salmon productivity. Additionally, more comprehensive, accurate and robust diet data will be an asset to ecosystem models, which are increasingly being applied in ecosystem-based management ${ }^{16}$. As salmon face an uncertain future with climate change $\mathrm{e}^{17,18}$, this is a critical time to consolidate available knowledge in order to advance research on salmon marine ecology.

${ }^{1}$ Institute for the Oceans and Fisheries, University of British Columbia, 2202 Main Mall, Vancouver, British Columbia, V6T 1Z4, Canada. '2Department of Earth, Ocean, and Atmospheric Sciences, University of British Columbia, 2207 Main Mall, Vancouver, British Columbia, V6T 1Z4, Canada. ${ }^{3}$ Hakai Institute, PO Box 25039, Campbell River, British

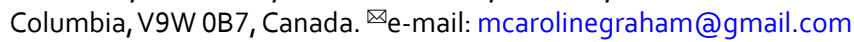


The goal of this project was to develop an open-access database framework for collating marine salmon diet data, alongside available salmon biological data, prey biological data, and environmental data. We compiled an initial contribution of salmon stomach content diet data from offshore areas using a systematic literature review, followed by quality control and standardization procedures for two time periods: 1959-1969 and 1987-1997. These decades were selected partially because they are time periods in which there are a larger quantity of data available on salmon diets. This database will continue to grow as more sources are identified and added and can be used as a tool by researchers to study salmon marine survival and North Pacific ecosystem dynamics.

\section{Methods}

Systematic literature review. In order to identify sources that contained salmon diet data, in the form of stomach contents, a systematic literature review was performed using database keyword searches of ProQuest: Aquatic Sciences and Fisheries Abstracts (https://search.proquest.com/asfa), Web of Science: Core Collection and Web of Science: Zoological Record (https://webofknowledge.com). Not all salmon diet studies are part of the peer-reviewed literature and many North Pacific researchers have published data through the North Pacific Anadromous Fish Commission (NPAFC) and the defunct International North Pacific Fisheries Commission (INPFC). Therefore, database search results were supplemented with relevant INPFC documents and bulletins (https://npafc.org/inpfc/), NPAFC documents (https://npafc.org/npafc-documents/) and bulletins (https://npafc. $\mathrm{org} / \mathrm{bulletin} /$ ), and relevant bibliographic references found within these documents and bulletins (Table 1).

The database keyword searches identified 591 unique sources. Sources were filtered for relevance and excluded based on the following criteria:

(i) the source did not have salmon stomach content diet data from between 1959-1969 or 1987-1997 for the marine environment, as defined by the area beyond the Riverine Coastal Domain $(\sim 15 \mathrm{~km})^{19}(556$ sources);

(ii) the source did not have extractable diet data and authors did not respond to inquiries (1 source);

(iii) the source was a review, in which case the original sources were used, if possible and relevant, to extract data (2 sources);

(iv) the source overlapped completely with another source, i.e., the data were reported using the exact same metrics for the same samples as another source (2 sources).

The database search was supplemented with sources that met the same criteria from the INPFC documents and bulletins and the NPAFC documents and bulletins, bringing the total number of unique sources to 62 (Online-only Table 1).

Data extraction. For each salmon diet sample, we extracted the following data (if available): source metadata (e.g., publication year, title, authors) (Online-only Table 2), salmon capture method (Online-only Table 3), site information (time, location), salmon information (e.g., taxonomy, life stage, sex), salmon replicates, type of diet data (e.g., percent weight of prey, total number of prey), and prey information (e.g., taxonomy, life stage, quantity) (Online-only Table 4). A diet sample is defined as a distinct sample in time and space from a specific source and is entered into the database exactly as it is reported in the source. A sample can contain diet data from one salmon or more than one salmon when individuals were grouped together for diet analysis (up to 2,215 in this data compilation). If different diet metrics were reported for the same diet sample (e.g., number of prey and volume of prey), then all metrics were entered into the database. If the data were not available in table format, but figure format only, then the data were extracted using WebPlotDigitizer (https://apps.automeris.io/wpd/).

For each source, we extracted data as it was presented in the sources in almost all cases, and therefore it was extracted according to the data resolution of the source. For example, if the sample location was presented as a station, it was extracted as a station with specific geographical coordinates, but if it was presented as a transect or area, then it was extracted as a transect or area with latitude and/or longitude minimums and maximums. If geographical coordinates were not specified, then they were estimated based on survey maps or descriptions present in the source. Prey taxonomy was reported to different resolutions across sources (e.g., Copepoda versus Neocalanus cristatus). In order to keep the lowest data resolution reported in the source while also being able to compare across sources, each prey item was reported at all possible taxonomic levels (kingdom, phylum, class, order, family, genus, species). In addition to the salmon diet data, if the source presented additional related data for salmon biological parameters (i.e., variables) (Online-only Table 5), prey biological parameters (Online-only Tables 6 and 7), or environmental parameters (Online-only Table 8), these data were extracted as well. For detailed information about the different types of data extracted and the extraction methodology see Online-only Tables 2-8.

Database framework. We built an open-access relational database in MySQL v8.0.18 called the "North Pacific Marine Salmon Diet Database"20,21. The North Pacific Marine Salmon Diet Database contains all of the extracted data noted above: diet data, salmon biological data, prey biological data, and environmental data. This database also allows for inclusion of prey biological data that are not associated with a salmon sample. For example, if a researcher conducted a zooplankton tow for potential prey and they have biological data for these potential prey (e.g., length, weight), these data can be added to the database. In this database, all data are linked by site, which has both a temporal and spatial component. All data are also related to a source in order to distinguish related data and trace its origins. While the database was built specifically to house North Pacific salmon diet data from the marine environment, the database structure was designed to easily be applied to other predator and prey interactions with only slight modifications. 


\begin{tabular}{|c|c|c|c|}
\hline Search terms & Source & $\begin{array}{l}\text { Results before } \\
\text { filtering }\end{array}$ & $\begin{array}{l}\text { Results after } \\
\text { filtering }\end{array}$ \\
\hline \multirow{8}{*}{$\begin{array}{l}\text { (Chinook OR "Oncorhynchus tshawytscha" OR coho OR } \\
\text { "Oncorhynchus kisutch" OR sockeye OR "Oncorhynchus nerka" OR } \\
\text { pink OR "Oncorhynchus gorbuscha" OR chum OR "Oncorhynchus } \\
\text { keta" OR steelhead OR "Oncorhynchus mykiss") } \\
\text { AND } \\
\text { (marine OR ocean* OR coast* OR "Gulf of Alaska" OR "Bering Sea") } \\
\text { AND } \\
\text { (stomach OR gut* OR "prey composition" OR "diet* composition" } \\
\text { OR "composition of diet" OR "composition of prey") } \\
\text { AND } \\
\text { (diet* OR prey OR food) }\end{array}$} & $\begin{array}{l}\text { Proquest: Aquatic Sciences and } \\
\text { Fisheries Abstracts }\end{array}$ & 410 & 23 \\
\hline & Web of Science: Core Collection & 182 & 6 \\
\hline & Web of Science: Zoological Record & 142 & 12 \\
\hline & $\begin{array}{l}\text { North Pacific Anadromous Fish } \\
\text { Commission Documents }\end{array}$ & & 23 \\
\hline & $\begin{array}{l}\text { North Pacific Anadromous Fish } \\
\text { Commission Bulletins }\end{array}$ & & 16 \\
\hline & $\begin{array}{l}\text { International North Pacific Fish } \\
\text { Commission Documents }\end{array}$ & & 5 \\
\hline & $\begin{array}{l}\text { International North Pacific } \\
\text { Fish Commission Bulletins }\end{array}$ & & 6 \\
\hline & & & Total $=62$ \\
\hline
\end{tabular}

Table 1. The number of salmon diet data sources identified from a systematic literature review. A keyword search was used to identify sources in three online databases (Proquest: Aquatic Sciences and Fisheries Abstracts, Web of Science: Core Collection, Web of Science: Zoological Record), which contained most of the peer-reviewed literature. The former steelhead species name "Salmo gairdneri", when included as a search term, did not provide any more relevant sources that met our criteria. A manual search through the NPAFC and INPFC documents and bulletins provided most of the gray literature. A total of 62 unique sources met the qualifications for database entry.

\section{Data Records}

The North Pacific Marine Salmon Diet Database currently contains 6,869 diet observations from 6,305 unique diet samples of over 69,942 salmon. Types of diet data included percent weight of prey, absolute weight of prey, average weight of prey, percent volume of prey, percent number of prey, absolute number of prey, average number of prey, frequency of occurrence (numerical and percent), stomach content index, index of fullness, and index of relative importance. The database also houses 11,965 observations of salmon biological parameters for 6,172 unique salmon samples. One observation means one biological parameter measured for one sample of salmon, which can contain one or many fish. Salmon biological parameters include length, weight, daily ration, empty stomachs, male/female ratio and many others. Additionally, the database includes 238 observations of prey biological parameters from 112 unique prey taxonomic categories. Prey biological parameters include body length, body weight, body width and size index. Finally, the database contains 2,790 observations of environmental parameters. Environmental parameters include temperature, salinity and others. These data are available in a static figshare repository ${ }^{22}$. The most current version of the relational database, associated documentation, and data are available in a dynamic GitHub repository, which will be updated as more sources are identified and added to the database ${ }^{21}$. Data were visualized using R statistical software v3.6.1 ${ }^{23}$.

Spatial and temporal coverage. Diet samples were collected at 751 unique spatial locations, which included areas (polygons), transects, and point locations across the North Pacific from the California Current to the Sea of Japan (Fig. 1). Salmon biological data were collected from 709 locations, prey biological data from 4 locations, and environmental data from 446 locations. Salmon biological data were reported across the entire North Pacific, while prey biological data were sparsely reported from a few locations in the Gulf of Alaska and the Sea of Okhotsk/Kuril Islands. Environmental data were mainly available from the eastern and central North Pacific Ocean. Since our search was focused on specific time periods, most of the data we collected fell within our specified decadal periods: 1959-1969 and 1987-1997 (Fig. 2). However, some sources reported data from other time periods and these data were also included in the database. While diet data and salmon biological data were consistently reported across the temporal range, environmental data and prey biological data were inconsistently reported.

Salmon and prey species coverage. Sockeye (Oncorhynchus nerka), pink (Oncorhynchus gorbuscha) and chum (Oncorhynchus keta) were reported most frequently in our database, while coho (Oncorhynchus kisutch), Chinook (Oncorhynchus tshawytscha) and steelhead (Oncorhynchus mykiss) were reported less frequently (Table 2). The most commonly reported prey groups were amphipods, fish (Class Actinopterygii), euphausiids, cephalopods (Subclass Coleoidea), and copepods (Table 3). The category 'miscellaneous' was also commonly reported, although it usually made up just a small percentage of the diets. Within the diet data reported in the database, there are 186 unique prey taxa, meaning the lowest taxonomic classifications of prey items. Only $18.5 \%$ of salmon diet data were reported to the species level, while the majority were reported to higher taxonomic levels (e.g., Amphipoda, Decapoda, Euphausiacea). 


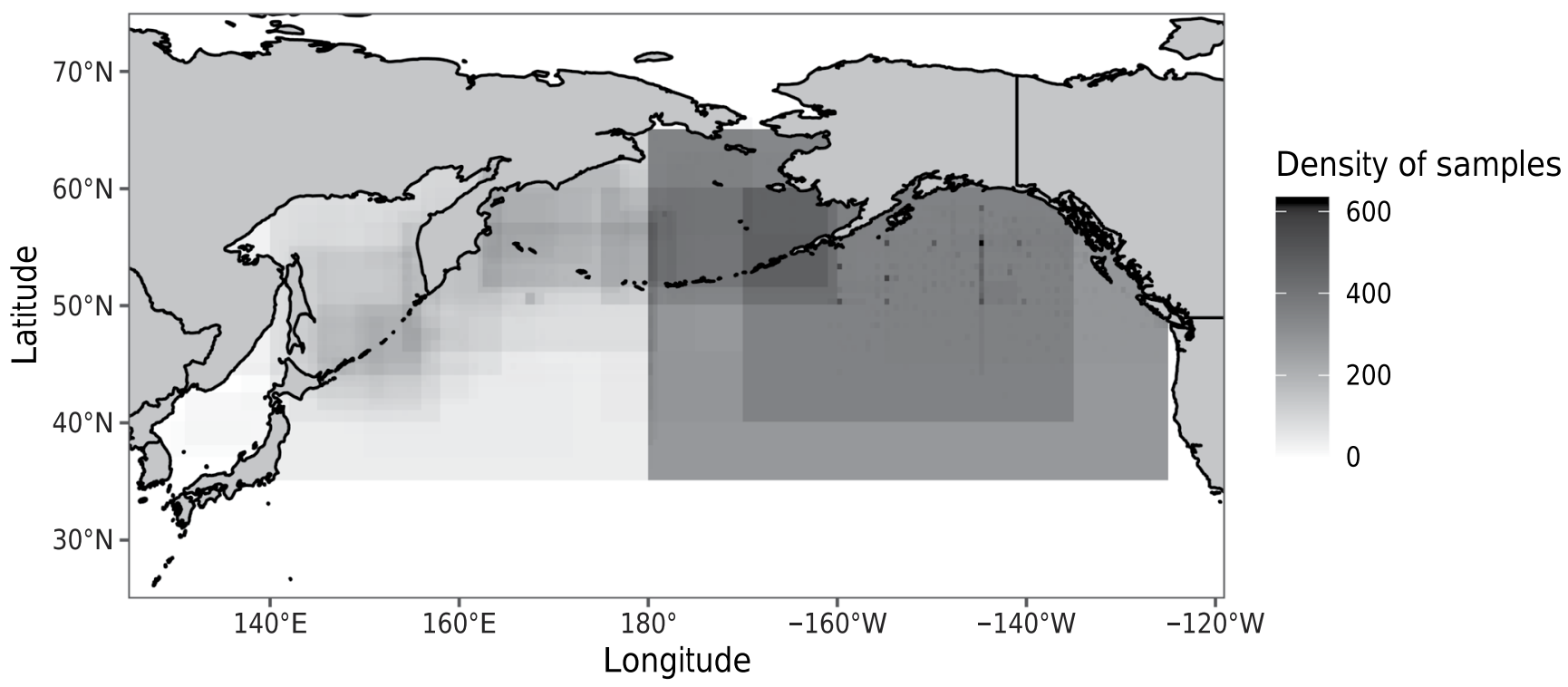

Fig. 1 The spatial distribution of diet samples across the North Pacific Ocean. The density of diet samples, in the form of points, lines, and polygons (rectangles) based on the latitude and longitude minimum and maximum values.

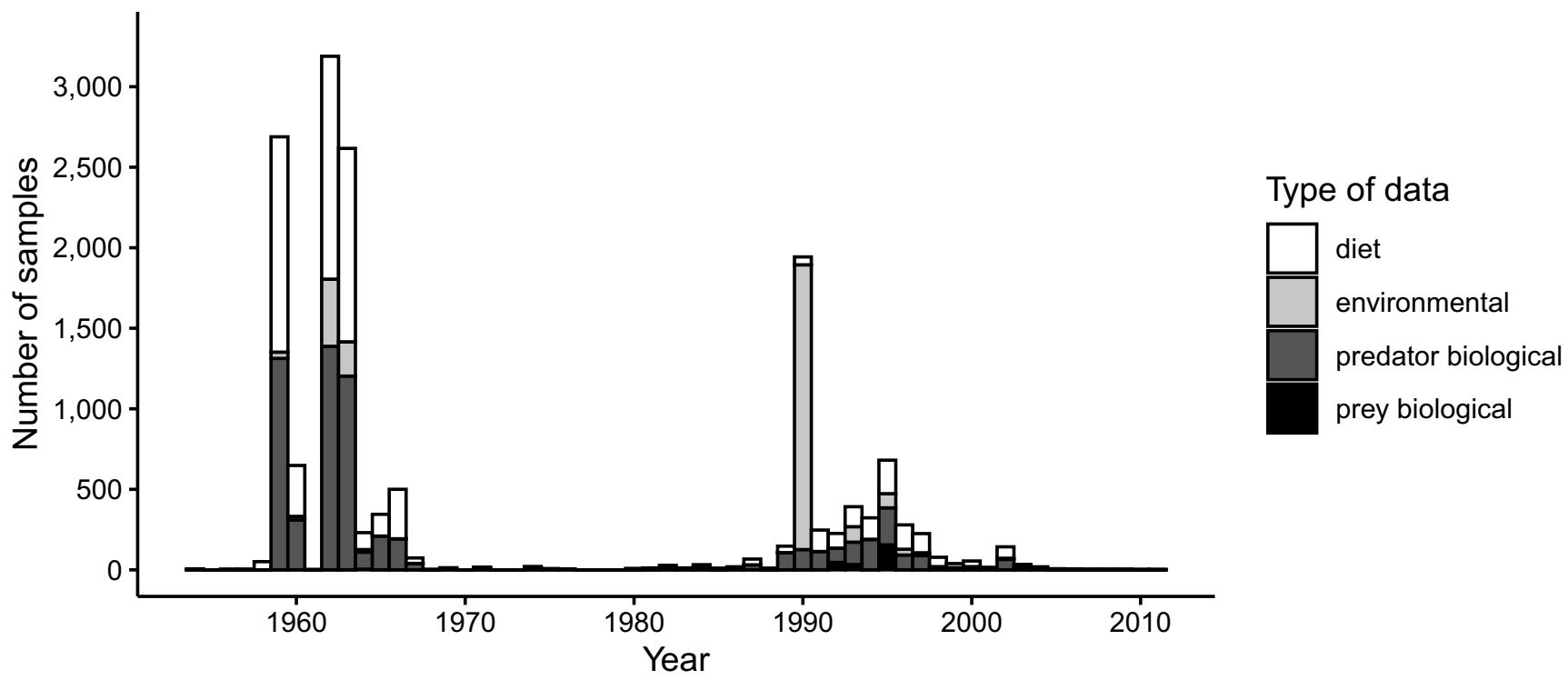

Fig. 2 The number of samples for each type of data reported across the temporal range 1950-2011. If a single sample consisted of data from multiple years, then the median year was selected to represent the sample and half years were rounded down.

\begin{tabular}{|l|l|}
\hline Salmon species & Number of samples \\
\hline Sockeye (Oncorhynchus nerka) & 2287 \\
\hline Pink (Oncorhynchus gorbuscha) & 1768 \\
\hline Chum (Oncorhynchus keta) & 1526 \\
\hline Coho (Oncorhynchus kisutch) & 293 \\
\hline Chinook (Oncorhynchus tshawytscha) & 271 \\
\hline Steelhead (Oncorhynchus mykiss) & 160 \\
\hline
\end{tabular}

Table 2. The number of diet samples in the database for each species of salmon. 


\begin{tabular}{|c|c|}
\hline Prey taxonomy & Number of samples \\
\hline Amphipoda & 2446 \\
\hline Actinopterygii & 2436 \\
\hline Euphausiacea & 2153 \\
\hline Miscellaneous & 2026 \\
\hline Coleoidea & 2009 \\
\hline Copepoda & 1460 \\
\hline Pteropoda & 697 \\
\hline Limacina & 595 \\
\hline Themisto japonica & 584 \\
\hline Thysanoessa longipes & 525 \\
\hline Limacina helicina & 438 \\
\hline Brachyura & 389 \\
\hline Neocalanus cristatus & 353 \\
\hline Clione limacina & 319 \\
\hline Hyperiidae & 299 \\
\hline Hemilepidotus & 290 \\
\hline Decapoda & 241 \\
\hline Anomura & 200 \\
\hline Gelatinous collective & 195 \\
\hline Euphausia pacifica & 180 \\
\hline Myctophidae & 179 \\
\hline Hyperia medusarum & 148 \\
\hline Polychaeta & 140 \\
\hline Calanoida & 131 \\
\hline Chaetognatha & 122 \\
\hline Cephalopoda & 118 \\
\hline Parasagitta elegans & 115 \\
\hline Primno macropa & 110 \\
\hline Sagitta & 96 \\
\hline Euphausiidae & 90 \\
\hline Rhynchonereella angelini & 79 \\
\hline Eucalanus bungii & 74 \\
\hline Neocalanus plumchrus & 73 \\
\hline Insecta & 68 \\
\hline Thysanoessa raschii & 68 \\
\hline Oikopleura & 67 \\
\hline Gadus chalcogrammus & 60 \\
\hline Clupea pallasii & 56 \\
\hline Gammaridae & 55 \\
\hline Themisto pacifica & 55 \\
\hline Gonatopsis borealis & 49 \\
\hline Crustacea & 47 \\
\hline Hyperia galba & 44 \\
\hline Mallotus villosus & 43 \\
\hline Gonatus kamtschaticus & 40 \\
\hline Mysida & 40 \\
\hline Ammodytes hexapterus & 39 \\
\hline Ammodytidae & 35 \\
\hline Thysanoessa inspinata & 35 \\
\hline Gonatidae & 33 \\
\hline Hexagrammidae & 32 \\
\hline Cnidaria & 29 \\
\hline Pleurogrammus & 28 \\
\hline Harpacticoida & 27 \\
\hline Themisto & 27 \\
\hline Berryteuthis magister & 26 \\
\hline \multicolumn{2}{|l|}{ Continued } \\
\hline
\end{tabular}




\begin{tabular}{|l|l|}
\hline Prey taxonomy & Number of samples \\
\hline Engraulis japonicus & 26 \\
\hline Nekton collective & 26 \\
\hline Thysanoessa inermis & 26 \\
\hline Tunicata & 25 \\
\hline Appendicularia & 23 \\
\hline Leuroglossus schmidti & 22 \\
\hline
\end{tabular}

Table 3. The number of diet samples containing each prey taxonomy. Prey taxonomy refers to the lowest taxonomic level identified by the source. Prey taxonomies that were reported in less than 20 samples were excluded.

\section{Technical Validation}

Standardization procedures were used to verify and collate the data. Since some of the taxonomic records were outdated, the taxonomies were verified and updated using the World Register of Marine Species (http://www. marinespecies.org/). For types of diet data that should add to a cumulative percentage of 100 (e.g., percent weight, percent volume), diet samples were excluded if the cumulative percent of prey was above $105 \%$ or below $95 \%$. If the cumulative percentage did not add to 100 but still fell within this range, diet data values for that sample were rescaled to add to 100 . For other metrics, including absolute and average weight and number of prey, as well as numerical frequency of occurrence, we consulted a salmon diet expert to determine if our highest values were reasonable to find in adult salmon stomachs (V. Zahner, pers. comm.).

\section{Usage Notes}

The North Pacific Marine Salmon Diet Database contains observations from many different sources, which report data with varying levels of detail. The method for data digitalization was to extract data as it was presented in the sources, or as close to it as possible. In this way, we have provided a more complete set of data that can be used for a variety of studies on salmon ecology and North Pacific ecosystems and left the manipulation and interpretation of data up to the discretion of the user.

The North Pacific Marine Salmon Diet Database is publicly available and can be used under the license of CC BY, meaning that the work can be distributed, remixed, adapted and built upon with acknowledgement of authors. There are a number of ways to access the information contained in the database. A static copy of the initial data contribution to the North Pacific Marine Salmon Diet Database described in this paper is available in a figshare repository in the form of seven csv files ('Diet_data,' 'Prey_biological_data', 'Sources', 'Predator_biological_data, 'Environmental_data', 'Gear_type_prey,' 'Gear_type_predator' ${ }^{22}$. In this case, 'predator' refers to salmon, but the database was designed so that it could easily be applied to other predator and prey interactions and thus we used the predator-prey terminology. Detailed information about the variables in the database can be found in Online-only Tables 2-8, which corresponds to the csv files in the figshare repository. To avoid making assumptions about how the data will be used, we have included all available data from the sources. This means that in some cases the same diet samples are reported multiple times using different diet metrics. In the figshare repository, there is R v3.6.1 code ('Preprocessing_data') to exclude overlapping data based on diet metrics of interest: presence/absence, weight/volume, frequency of occurrence, and numerical.

A dynamic version of the North Pacific Marine Salmon Diet Database can be accessed through a GitHub repository and will be updated as more historic data are digitized and made available by the Pelagic Ecosystems Laboratory at the University of British Columbia ${ }^{21}$. The GitHub repository contains updated versions of the files found in the figshare repository, in addition to documentation for the North Pacific Marine Salmon Diet Database ('npmsdd_documentation'), a data entry template ('npmsdd_data_entry_template'), and a dumped version of the MySQL relational database ('npmsdd_MySQL_database_dump') for users that are interested in working with the database in the relational database format.

\section{Code availability}

The figshare repository contains R v3.6.1 code for downstream data processing ('Preprocessing_data'), and code to create the figures that appear in this publication ('Publication_figures') ${ }^{22}$. The GitHub repository contains the most up-to-date code for downstream data processing ${ }^{21}$.

Received: 14 May 2020; Accepted: 4 September 2020;

Published online: 06 October 2020

\section{References}

1. Pacific Salmon Life Histories. (eds. Groot, C \& Margolis, L.) (University of British Columbia Press, 1991).

2. Beamish, R. J. \& Mahnken, C. A critical size and period hypothesis to explain natural regulation of salmon abundance and the linkage to climate and climate change. Prog. Oceanogr. 49, 423-437 (2001).

3. Bradford, M. J. Comparative review of Pacific salmon survival rates. Can. J. Fish. Aquat. Sci. 52, 1327-1338 (1995).

4. Mueter, F. J., Peterman, R. M. \& Pyper, B. J. Corrigendum: Opposite effects of ocean temperature on survival rates of 120 stocks of Pacific salmon (Oncorhynchus spp.) in northern and southern areas. Can. J. Fish. Aquat. Sci. 60, 757-757 (2003).

5. Zimmerman, M. S. et al. Spatial and temporal patterns in smolt survival of wild and hatchery coho salmon in the Salish Sea. Mar. Coast. Fish. 7, 116-134 (2015).

6. Dale, K. E., Daly, E. A. \& Brodeur, R. D. Interannual variability in the feeding and condition of subyearling Chinook salmon off Oregon and Washington in relation to fluctuating ocean conditions. Fish. Oceanogr. 26, 1-16 (2017).

7. Davis, N. D. et al. Review of BASIS salmon food habits studies. North Pacific Anadromous Fish Comm. Bull. 5, 197-208 (2009).

8. Qin, Y. \& Kaeriyama, M. Feeding habits and trophic levels of Pacific salmon (Oncorhynchus spp.) in the North Pacific Ocean. North Pacific Anadromous Fish Comm. Bull. 6, 469-481 (2016). 
9. Chapman, W. M. The Pilchard Fishery of the State of Washington in 1936 with Notes on the Food of the Silver and Chinook Salmon off the Washington Coast. Biological Report No. 36C (State of Washington, Division of Scientific Research, Department of Fisheries, 1936).

10. Silliman, R. P. Fluctuations in the diet of the Chinook and silver salmons (Oncorhynchus tschawytscha and O. kisutch) off Washington, as related to the troll catch of salmon. Copeia 1941, 80-87 (1941).

11. Brodeur, R. D., Daly, E. A., Schabetsberger, R. A. \& Mier, K. L. Interannual and interdecadal variability in juvenile coho salmon (Oncorhynchus kisutch) diets in relation to environmental changes in the northern California Current. Fish. Oceanogr. 16, 395-408 (2007).

12. Brodeur, R. D. A Synthesis of the Food Habits and Feeding Ecology of Salmonids in Marine Waters of the North Pacific. INPFC Doc; FRI-UW-9016. (Fisheries Research Institute, University of Washington, 1990).

13. Karpenko, V. I., Volkov, F. \& Koval, M. V. Diets of Pacific salmon in the Sea of Okhotsk. Bering Sea, and Northwest Pacific Ocean. North Pacific Anadromous Fish Comm. Bull. 4, 105-116 (2007).

14. Starovoytov, A. N. Trends in abundance and feeding of chum salmon in the Western Bering Sea. North Pacific Anadromous Fish Comm. Bull. 4, 45-51 (2007).

15. Kaeriyama, M. et al. Change in feeding ecology and trophic dynamics of Pacific salmon (Oncorhynchus spp.) in the central Gulf of Alaska in relation to climate events. Fish. Oceanogr. 13, 197-207 (2004).

16. Jamieson, G., Livingston, P. \& Zhang, C.-I. Report of Working Group 19 on Ecosystem-based Management Science and its Application to the North Pacific. PICES Scientific Report 37 (North Pacific Marine Science Organization, 2010),

17. Schoen, E. R. et al. Future of Pacific salmon in the face of environmental change: Lessons from one of the world's remaining productive salmon regions. Fisheries 42, 538-553 (2017).

18. Healey, M. The cumulative impacts of climate change on Fraser River sockeye salmon (Oncorhynchus nerka) and implications for management. Can. J. Fish. Aquat. Sci. 68, 718-737 (2011).

19. Carmack, E., Winsor, P. \& Williams, W. The contiguous panarctic Riverine Coastal Domain: A unifying concept. Prog. Oceanogr. 139, 13-23 (2015).

20. MySQL version 8.0.18. MySQL, https://www.mysql.com/ (2019).

21. Graham, C, Pakhomov, E. A., \& Hunt, B. P. V. North Pacific Marine Salmon Diet Database. GitHub, https://github.com/ mcarolinegraham/North_Pacific_Marine_Salmon_Diet_Database (2020).

22. Graham, C, Pakhomov, E. A., \& Hunt, B. P. V. A salmon diet database for the North Pacific Ocean. figshare https://doi.org/10.6084/ m9.figshare.c.4974128 (2020)

23. R Core Development Team. R: A language and environment for statistical computing, version 3.6.1. The R Project for Statistical Computing https://www.r-project.org/ (2019).

24. Andrievskaya, L. D. Food relationships of the Pacific salmon in the sea. Vopr. Ikhtiologii 6, 84-90 (1966).

25. Carlson, H. R. Foods of juvenile sockeye salmon, Oncorhynchus nerka, in the inshore coastal waters of Bristol Bay, Alaska, 1966-67. Fish. Bull. 74, 458-462 (1976).

26. Chuchukalo, V. L., Volkov, A. F., Efimkin, A. Y. \& Kuznetsova, N. A. Feeding and Daily Rations of Sockeye Salmon (Oncorhynchus nerka) During the Summer Period. NPAFC Doc. 125 (Pacific Research Institute of Fisheries Oceanography (TINRO), 1995).

27. Davis, N. D., Takahashi, M. \& Ishida, Y. The 1996 Japan-U.S. Cooperative High-seas Salmon Research Cruise of the Wakatake maru and a Summary of 1991-1996 Results. NPAFC Doc. 194; FRI-UW-9617 (Fisheries Research Institute, University of Washington; National Research Institute of Far Seas Fisheries, 1996).

28. Davis, N. D., Aydin, K. Y. \& Ishida, Y. Diel Feeding Habits and Estimates of Prey Consumption of Sockeye, Chum, and Pink Salmon in the Bering Sea in 1997. NPAFC Doc. 363; FRI-UW-9816 (Fisheries Research Institute, University of Washington; National Research Institute of Far Seas Fisheries, 1998).

29. Davis, N. D., Aydin, K. Y. \& Ishida, Y. Diel catches and food habits of sockeye, pink, and chum salmon in the Central Bering Sea in summer. North Pacific Anadromous Fish Comm. Bull. 2, 99-109 (2000).

30. Dulepova, E. P. \& Dulepov, V. I. Interannual and Interregional Analysis of Chum Salmon Feeding Features in the Bering Sea and Adjacent Pacific Waters of Eastern Kamchatka. NPAFC Doc. 728 (Pacific Research Fisheries Centre, TINRO-Centre, 2003).

31. Fukataki, H. Stomach contents of the pink salmon, Oncorhynchus gorbuscha (Walbaum), in the Japan Sea during the spring season of 1965. Bull. Jap. Sea Reg. Fish. Res. Lab. 17, 49-66 (1967).

32. Glebov, I. I. Chinook and Coho Salmon Feeding Habits in the Far Eastern Seas in the Course of Yearly Migration Cycle. NPAFC Doc. 378 (Pacific Research Fisheries Centre TINRO-Centre, 1998).

33. Ito, J. Food and feeding habits of Pacific salmon (genus Oncorhynchus) in their oceanic life. Bull. Hokkaido Reg. Fish. Res. Lab. 29, $85-97(1964)$

34. Kaeriyama, M. et al. Feeding ecology of sockeye and pink salmon in the Gulf of Alaska. North Pacific Anadromous Fish Comm. Bull. 2, 55-63 (2000).

35. Kanno, Y. \& Hamai, I. Food of salmonid fish in the Bering Sea in summer of 1966. Bull. Fac. Fish. Hokkaido Univ. 22, 107-128 (1971).

36. Manzer, J. I. Food of Pacific salmon and steelhead trout in the Northeast Pacific Ocean. J. Fish. Res. Board Canada 25, 1085-1089 (1968).

37. Perry, R. I., Hargreaves, N. B., Waddell, B. J. \& Mackas, D. L. Spatial variations in feeding and condition of juvenile pink and chum salmon off Vancouver Island, British Columbia. Fish. Oceanogr. 5, 73-88 (1996).

38. Tadokoro, K., Ishida, Y., Davis, N. D., Ueyanagi, S. \& Sugimoto, T. Change in chum salmon (Oncorhynchus keta) stomach contents associated with fluctuation of pink salmon (O. gorbuscha) abundance in the central subarctic Pacific and Bering Sea. Fish. Oceanogr. 5, 89-99 (1996).

39. Takeuchi, I. Food animals collected from the stomachs of three salmonid fishes (Oncorhynchus) and their distribution in the natural environments in the northern North Pacific. Bull. Hokkaido Reg. Fish. Res. Lab. 38, 1-119 (1972).

40. Ueno, M., Kosaka, S. \& Ushiyama, H. Food and feeding behavior of Pacific salmon-II. Sequential change of stomach contents. Bull. Japanese Soc. Sci. Fish. 35, 1060-1066 (1969).

41. Volkov, A. F., Chuchukalo, V. I., Efimkin, A. Y. Feeding of Chinook and Coho Salmon in the Northwestern Pacific Ocean. NPAFC Doc. 124 (Pacific Research Institute of Fisheries Oceanography, 1995).

42. Auburn, M. E. \& Ignell, S. E. Food habits of juvenile salmon in the Gulf of Alaska July-August 1996. North Pacific Anadromous Fish Comm. Bull. 2, 89-97 (2000).

43. Aydin, K. Y. Abiotic and Biotic Factors Influencing Food Habits of Pacific Salmon in the Gulf of Alaska. In Technical report: Workshop of Climate Change and Salmon Production (ed. Myers, K. W.) 39-40 (North Pacific Anadromous Fish Commission, 1998).

44. Daly, E. A. \& Brodeur, R. D. Warming ocean conditions relate to increased trophic requirements of threatened and endangered salmon. PLoS One 10, e0144066 (2015).

45. Davis, N. D., Armstrong, J. L. \& Myers, K. W. Bering Sea Salmon Food Habits: Diet Overlap in Fall and Potential for Interactions Among Salmon. SAFS-UW-0311 (Fisheries Research Institute, School of Aquatic and Fisheries Sciences, University of Washington, 2003).

46. Kawamura, H., Miyamoto, M., Nagata, M. \& Hirano, K. Interaction between chum salmon and fat greenling juveniles in the coastal Sea of Japan off northern Hokkaido. North Pacific Anadromous Fish Comm. Bull. 1, 412-418 (1998).

47. Ueno, Y. Deepwater migrations of chum salmon (Oncorhynchus keta) along the Pacific coast of northern Japan. Can. J. Fish. Aquat. Sci. 49, 2307-2312 (1992)

48. Ueno, Y., Seki, J., Shimizu, I. P. \& Shershnev, A. Large juvenile chum salmon Oncorhynchus keta collected in coastal waters of Iturup Island. Nippon Suisan Gakkaishi 58, 1393-1397 (1992). 
49. Waddell, B. J., Morris, J. F. T. \& Healey, M. C. The abundance, distribution, and biological characteristics of Chinook and coho salmon on the fishing banks off southwest Vancouver Island, May 18-30, 1989 and April 23-May 5, 1990. Can. Tech. Rep. Fish. Aquat. Sci. 1891, 1-113 (1992).

50. Andrievskaya, L. D. The feeding of Pacific salmon fry in the sea. Proceedings of the Pacific Research Institute of Fisheries and Oceanography 64, 73-80 (1970).

51. Atcheson, M. E., Myers, K. W., Beauchamp, D. A. \& Mantua, N. J. Bioenergetic response by steelhead to variation in diet, thermal habitat, and climate in the North Pacific Ocean. Trans. Am. Fish. Soc. 141, 1081-1096 (2012).

52. Carlson, H. R. et al. Cruise Report of the F/V Great Pacific Survey of Young Salmon in the North Pacific-Dixon Entrance to Western Aleutians-July-August 1996. NPAFC Doc. 222 (Auke Bay Laboratory, Alaska Fisheries Science Center, National Marine Fisheries Service, National Oceanic and Atmospheric Administration, 1996).

53. Davis, N. D., Fukuwaka, M., Armstrong, J. L. \& Myers, K. W. Salmon food habits studies in the Bering Sea. 1960 to present. North Pacific Anadromous Fish Comm. Tech. Rep. 6, 24-28 (2005).

54. Myers, K. W. \& Aydin, K. Y. The 1996 International Cooperative Salmon Research Cruise of the Oshoro maru and a Summary of 19941996 Results. NPAFC Doc. 195; FRI-UW-9613 (University of Washington, Fisheries Research Institute, 1996).

55. Myers, K. W. et al. Migrations, Abundance, and Origins of Salmonids in Offshore Waters of the North Pacific - 1995. NPAFC Doc. 152; FRI-UW-9613 (University of Washington, Fisheries Research Institute, 1995).

56. Sturdevant, M. V, Ignell, S. E. \& Morris, J. Diet of Juvenile Salmon off Southeastern Alaska, October-November 1995. NPAFC Doc. 275 (Auke Bay Laboratory, Alaska Fisheries Science Center, National Marine Fisheries Service, National Oceanic and Atmospheric Administration, 1997).

57. Walker, R. V. Summary of Cooperative U.S.-Japan High Seas Salmonid Research Aboard the Japanese Research Vessel Oshoro Maru, 1993. NPAFC Doc. 21 (Fisheries Research Institute, University of Washington, 1993).

58. Suzuki, T. et al. Feeding selectivity of juvenile chum salmon in the Japan Sea Coast of Northern Honshu. Sci. Reports Hokkaido Salmon Hatch. 48, 11-16 (1994).

59. Shimazaki, K. \& Mishima, S. On the diurnal change of the feeding activity of salmon in the Okhotsk Sea. Bull. Fac. Fish. Hokkaido University 20, 82-93 (1969).

60. Weitkamp, L. A. Ocean Conditions, Marine Survival, and Performance of Juvenile Chinook (Oncorhynchus tshawytscha) and Coho (O. kisutch) Salmon in Southeast Alaska. PhD thesis, University of Washington (2004).

61. Starovoytov, A. N. Chum salmon (Oncorhynchus keta (Walbaum)) in the Far East Seas - biological description of the species 2. Diet composition and trophic linkages of chum salmon in the Far East Seas and adjacent waters of the Northwest Pacific Ocean. Izv. TINRO 133, 3-34 (2003).

62. LeBrasseur, R. J. \& Doidge, D. A. Stomach Contents of Salmonids Caught in the Northeastern Pacific Ocean - 1959 \& 1960. In Circular, Statistical Series. vol. 3 (Fisheries Research Board of Canada, 1966).

63. Lebrasseur, R. J. \& Doidge, D. A. Stomach Contents of Salmonids Caught in the Northeastern Pacific Ocean - 1962. In Circular, Statistical Series. vol. 4 (Fisheries Research Board of Canada, 1966).

64. Lebrasseur, R. J. \& Doidge, D. A. Stomach Contents of Salmonids Caught in the Northeastern Pacific Ocean - 1963 \& 1964. In Circular, Statistical Series. vol. 5 (Fisheries Research Board of Canada, 1966).

65. Ishida, Y. \& Davis, N. D. Chum salmon feeding habits in relation to growth reduction. Salmon Rep. Ser. 47, 104-110 (1999).

66. Tamura, R., Shimazaki, K. \& Ueno, Y. Trophic relations of juvenile salmon (genus Oncorhynchus) in the Okhotsk Sea and Pacific waters off the Kuril Islands. Salmon Rep. Ser. 47, 138-168 (1999).

67. Seki, J. \& Shimizu, I. Diel migration of zooplankton and feeding behavior of juvenile chum salmon in the central Pacific coast of Hokkaido. Bull. Nat. Salmon Resour. Cent. 1, 13-27 (1998).

68. Suzuki, T., Fukuwaka, M., Kawana, M., Ohkuma, K. \& Seki, J. Investigation on survival mechanism of juvenile chum salmon during the early sea life in 1994. Salmon Database 3, 59-68 (1995).

69. Andrievskaya, L. D. The feeding of pink salmon in the wintering areas in the Sea of Japan. Izv. TINRO 90, 97-110 (1974).

70. Andrievskaya, L. D. Feeding of Pacific salmon juveniles in the Sea of Okhotsk. Izv. TINRO 78, 105-115 (1970).

71. Chuchukalo, V. I., Volkov, A. F., Efimkin, Ay. \& Blagoderov, A. I. Distribution and feeding of the Chinook salmon (Oncorhynchus tschawytscha) in the northwest Pacific. Izv. TINRO, 137-141 (1994).

72. Gorbatenko, K. M. Food and feeding habits of juvenile pink and chum salmons in the epipelagic zone of the Okhotsk Sea in winter. Izv. TINRO 199, 234-243 (1996).

73. Kayev, A. M., Chupakhin, V. M. \& Fedotova, N. A. Feeding peculiarities and interrelationships between juvenile salmons in coastal waters of the Etorofu Island. Vopr. Ikhtiologii 33, 215-224 (1993).

74. Klovatch, N. V. Ecological Consequences of Large-scale Breeding Operations of Chum Salmon (Oncorhynchus keta). PhD extended summary (VNIRO, 2002).

75. Shershnev, A. P., Chupakhin, V. M. \& Rudnev, V. A. Some features of the ecology of young Sakhalin and Iturup pink salmon Oncorhynchus gorbuscha (Walbaum) (Salmonidae) during marine period of life. Vopr. Ikhtiologii 22, 441-448 (1982).

76. Tutubalin, B. G. \& Chuchukalo, V. I. The Feeding of Genus Oncorhynchus Pacific Salmons in the North Pacific During the WinterSpring Period. In Living Resources of the Pacific Ocean: Collected Papers (eds. Gristenko, O. F., Churikov, A. A. \& Klovach, N. V.) 77-85 (VNIRO, 1992).

77. Volkov, A. F. Food and feeding habits of young Pacific salmon in the Okhotsk Sea during the autumn-winter period. Okeanologiya 36, 80-85 (1996).

78. Volkov, A. F. Food and feeding habits of pink, chum and sockeye salmon during their anadromous migrations. Izv. TINRO 116, 128-137 (1994).

79. Fisheries Agency of Japan. Report on research by Japan for the International North Pacific Fisheries Commission during the year 1965. International North Pacific Fisheries Commission Ann. Rep., 42-55 (1965).

80. Davis, N. D. U.S.-Japan Cooperative High Seas Salmonid Research in 1990: Summary of Research Aboard the Japanese Research Vessel Hokuho Maru, 4 June to 19 July. INPFC Doc.; FRI-UW-9010. (Fisheries Research Institute, University of Washington, 1990).

\section{Acknowledgements}

This project was made possible by funding from the Ambrose Monell and G. Unger Vetlesen Foundations, and the University of British Columbia. We would like to acknowledge Raymond $\mathrm{Ng}$ for his guidance on the database design, Sally Taylor for her help in the literature review process, Tim Cashion for his assistance with figures, and Marina Espinasse and Carmen Manuel for their assistance with data entry. We would also like to acknowledge Svetlana Naydenko, Alexey Khoruzhiy and Alexei Somov for helping to locate sources of data and Tim Spesivy and Kyoko Adachi for translating Russian and Japanese sources.

\section{Author contributions}

Caroline Graham: systematic literature review, data extraction and standardization, database structure and creation, drafting and revision of the article. Evgeny A. Pakhomov: project concept, project funding, revision of the article. Brian P. V. Hunt: project concept, project funding, database structure, revision of the article. 


\title{
Competing interests
}

The authors declare no competing interests.

\section{Additional information}

Correspondence and requests for materials should be addressed to C.G.

Reprints and permissions information is available at www.nature.com/reprints.

Publisher's note Springer Nature remains neutral with regard to jurisdictional claims in published maps and institutional affiliations.

\begin{abstract}
(c) (i) Open Access This article is licensed under a Creative Commons Attribution 4.0 International (c) License, which permits use, sharing, adaptation, distribution and reproduction in any medium or format, as long as you give appropriate credit to the original author(s) and the source, provide a link to the Creative Commons license, and indicate if changes were made. The images or other third party material in this article are included in the article's Creative Commons license, unless indicated otherwise in a credit line to the material. If material is not included in the article's Creative Commons license and your intended use is not permitted by statutory regulation or exceeds the permitted use, you will need to obtain permission directly from the copyright holder. To view a copy of this license, visit http://creativecommons.org/licenses/by/4.0/.
\end{abstract}

The Creative Commons Public Domain Dedication waiver http://creativecommons.org/publicdomain/zero/1.0/ applies to the metadata files associated with this article.

(c) The Author(s) 2020 